\title{
Large placental hemangioma diagnosed by ultrasonography - a case report
}

Obstetrics Service, Hospital Santo Amaro (Fundação José Silveira); Pathological Anatomy Department, Medical School, Universidade Federal da Bahia, Salvador - BA, Brazil

We present a case of large placental hemangioma comprising more than half of the organ and not causing feto-maternal complications. It appeared after 29 weeks of gestation. At 29 weeks an ultrasonography disclosed a normal placenta. At 35 weeks of gestation it measured $60 \times 57 \mathrm{~mm}$ and appeared as a well delineated hypoechoic image. Delivery took place at 38 weeks by cesarean section and the child was normal.

UNITERMS: Chorioangiomas. Placental ultrasound. Placental pathology.

\section{INTRODUCTION}

$\mathrm{P}$ lacental hemangiomas (chorioangiomas) occur in about $1 \%$ of placentas, but the majority of these tumors measure less than one centimeter and are not observed at inspection of the organ (3).

Large tumors are rare and may cause various clinical complications in the mother and fetus/newborn. Fetal cardiomegaly, congestive heart failure and hydropsy have been attributed to shunting of blood through the hemangioma.
Other fetal complications associated with tumors, larger than $5 \mathrm{~cm}$, are fetal growth retardation, anemia, thrombocytopenia, disseminated intravascular coagulation and hemangiomas in other fetal areas. These large tumors are generally accompanied by hydramnios, pre-eclampsia and premature delivery (2).

Hemangiomas in other tissues of the body are chäracterized by a very slow growth and lack of capsulation. However, in the placenta, these tumors are capsulated and grow faster. In this paper, a case of a large placental hemangioma diagnosed by ultrasonography (US) that caused no disturbances in the mother and fetus is discussed.

\author{
Address for correspondence: \\ Achiléa Lisboa Bittencourt \\ Hospital Prof. Edgard Santos - Univers. Federal da Bahia \\ Serviço de Anatomia Patológica \\ Rua João das Botas s/n, Canela \\ Salvador/BA - Brasil - CEP 40110-160
}

\section{CASE REPORT}

A 28-year-old woman, G3 P1, began to have prenatal care at eight weeks of gestation. In the 17 th week of 


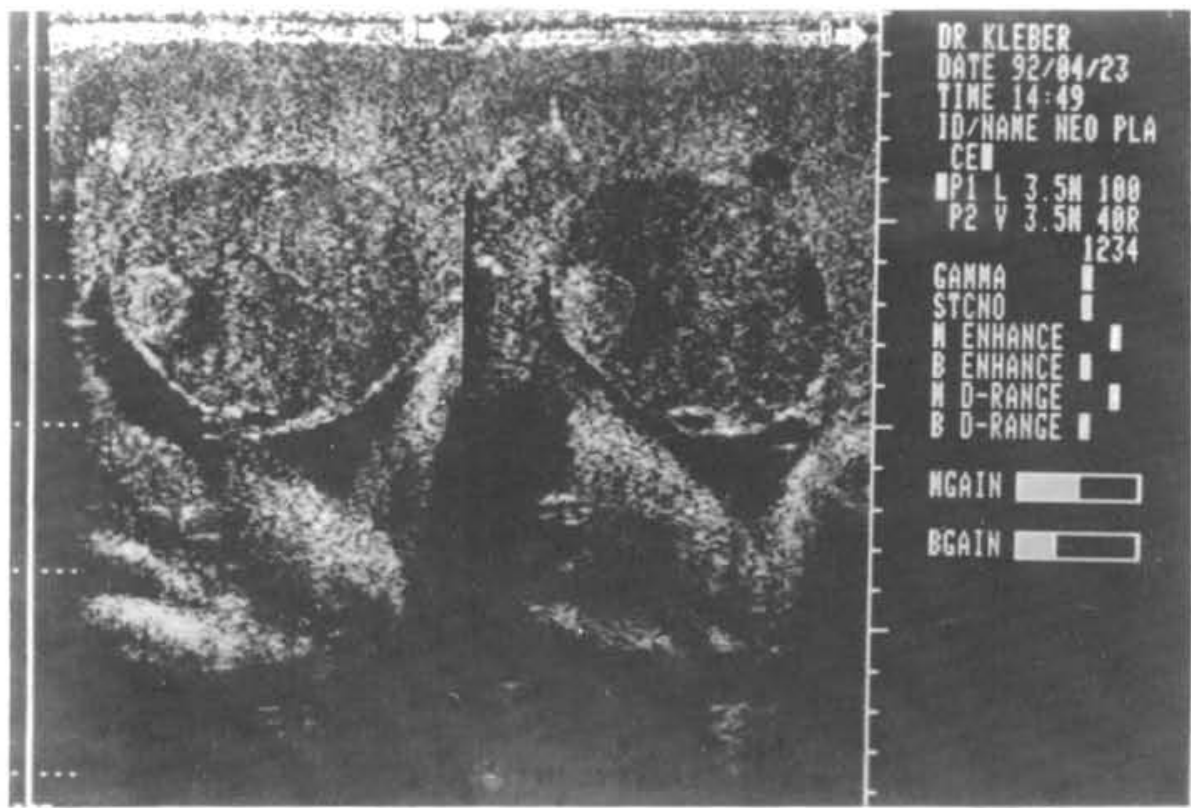

FIGURE 1 - Ultrasonography shows a well-delineated hypoechoic image with a small echogenic round area at the left.

gestation, a routine ultasonography (US) yielded normal results. In the her first pregnancy she had provoked abortion. Her second pregnancy, three years ago, resulted in a term vaginal delivery of a healthy child. The course of the present pregnancy was uneventful until the 29th week, when she began to present uterine contractions. At this time, the US was normal.

She was recommended to rest and was treated with betamimetics (Brycanil).

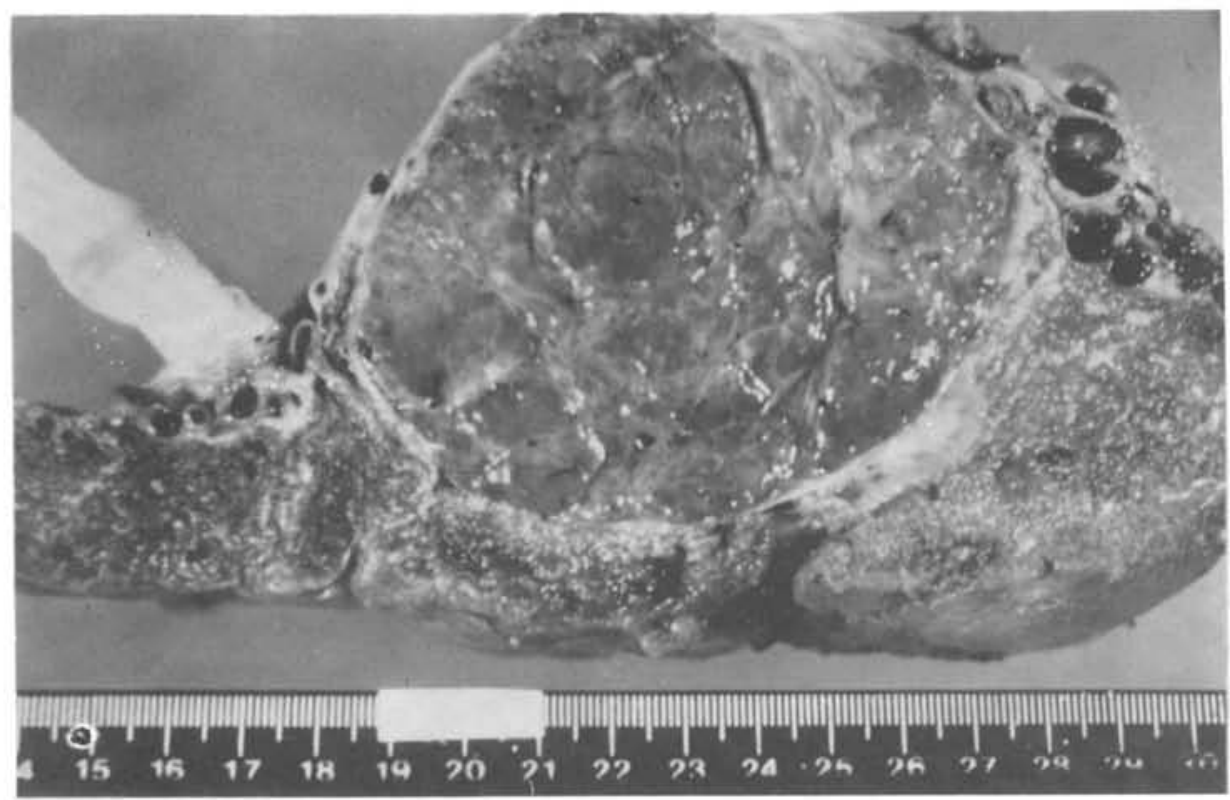

FIGURE 2 - Cut surface of the tumor showing a large and tumor surrounded by a thin capsule.
She was re-evaluated ultrasonographically at 35 weeks when a $60 \times 57 \mathrm{~mm}$ subchorionic lesion was visualized in an anterior placenta. It consisted of a well delineated hypoechoic image with a small echogenic round area (Fig.1). The echographic diagnosis was hemangioma. Ultrasonographically, the fetus presented normal biometrical parameters for the gestational age without cardiomegaly or hepatomegaly. Delivery took place at 38 weeks of gestation by cesarean section and was uneventful. The male child was born weighing $3.420 \mathrm{~g}$. Echocardiography and abdominal US of the newborn did not disclose cardiac or hepatic alterations and a hematological evaluation was normal.

The placenta weighed $500 \mathrm{~g}$ and measured $18 \times 13$ $\mathrm{cm}$. A large tumor measuring $6 \times 6 \mathrm{~cm}$ bulged on the surface. It was subchorionic and presented a fleshy and red cut surface, well delineated by a thin capsule (Fig.2). The umbilical cord was normal. Microscopically, the tumor consisted of small vessels within a myxedematous stroma (Fig.3). It was delineated by a fibrous capsule and exhibited the aspect of a capillary hemangioma. The placental villi were normal for the gestational age, although they presented more capillaries than is normally observed (chorioangiosis).

\section{DISCUSSION}

According to Philippe (5), placental hemangiomas generally appear after 30 weeks gestation. However, there are two reports of chorionangiomas diagnosed at 22 and 25 weeks by ultrasonography $(1,4)$. In the present case, the tumor appeared after 29 weeks of gestation and showed a rapid growth, reaching $60 \times 57 \mathrm{~mm}$ in less than six weeks, 
The tumor was subchorionic, close to the umbilical cord, and comprised more than half of the placental parenchyma. In spite of this, the child was born without complications. It was submitted to an echocardiographic study and to an abdominal ultrasonography in order to search for cardiac enlargement and abdominal tumors, respectively, but no abnormalities were observed. In addition, no hemangio-

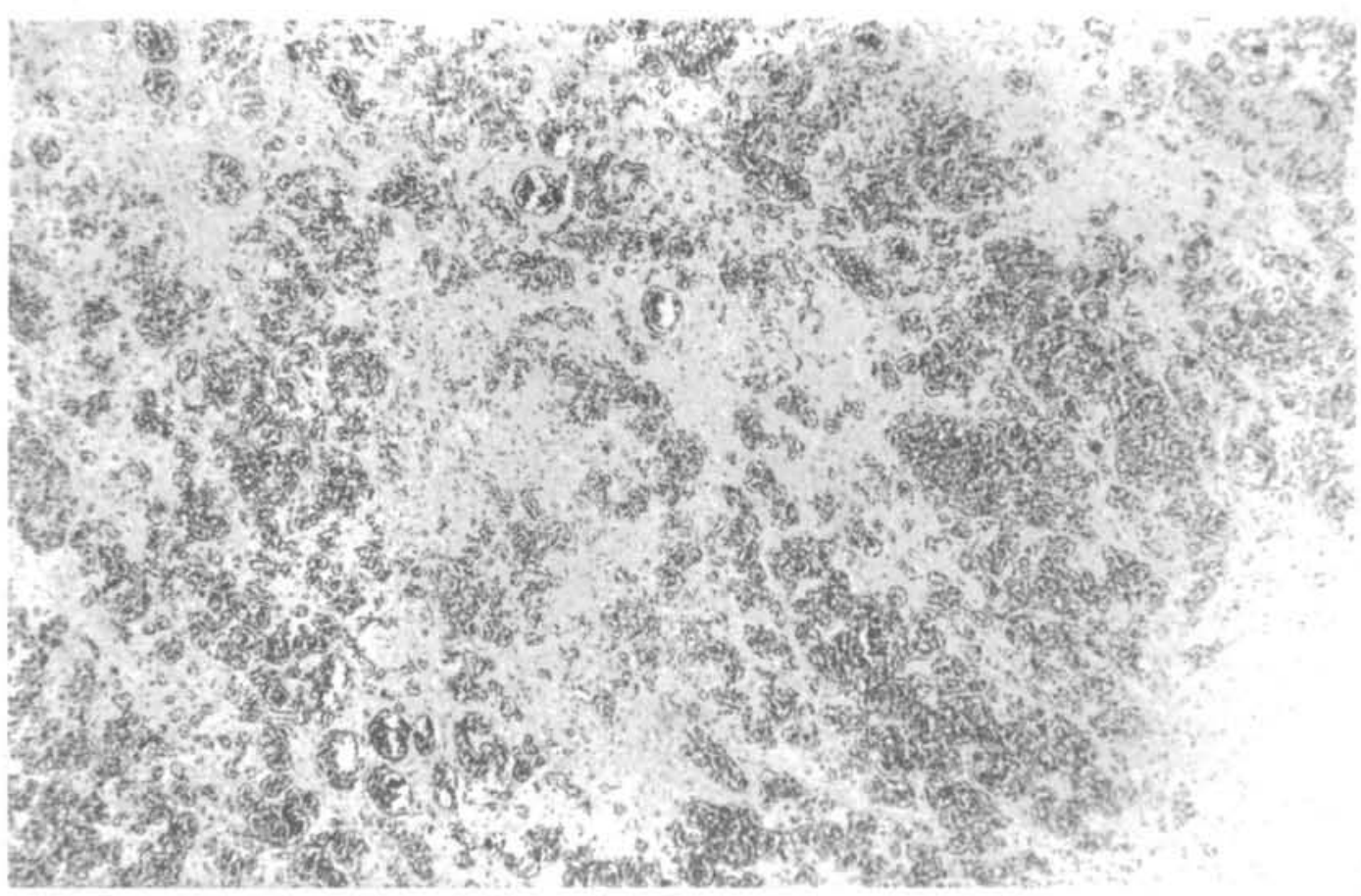

FIGURE 3 - Microscopical section of the tumor show any small blood within a myxomatous stroma. HE, 40x. mas were seen in the newborn's skin. Probably, the chorioangiosis observed in the placental villi resulted from a compensatory mechanism because of the reduction of the functional parenchyma.

The present case is unusual because the very large placental hemangioma did not cause abnormalities in the conceptus, and the pregnancy was uneventful.

The ultrasonographic and placental examinations indicated a rapid growth of the hemangioma.

\section{Resumo}

Introdução: Apresenta-se um caso de volumoso hemangioma placentário envolvendo mais de metade do órgẫo sem causar complicaçōes feto-maternas. Resultados: Com 29 semanas a placenta era normal ao ultra-som e com 35 semanas já exibia imagem hipoecóica com $60 \times 57 \mathrm{~cm}$. O parto ocorreu com 38 semanas sem intercorrências e o recém-nascidó nāo apresentou alteraçōes.

\section{REFERENCES}

1. ACHIRON, R; SHAIA, M; SHIMMED, $M$ et al. . Choriongioma with hydrops in twins. The Fetus 2: 1, 1992.

2. BENIRSCHKE, K. \& KAUFMAN, P. - Pathology of the Human Placenta, New York, Springer-Verlag, 1990, p 841.

3. BITTENCOURT, A.L. - Tumores Primários da Placenta. Não Trofoblásticos, in Garcia, A; Azoubel, R. (eds): A placenta humana. Morfologia e Patologia Fetal e Perinatal. Rio de Janeiro, Atheneu, 1986, p187.

4. DAO, A.H.; ROGERS, W. \& WONG, S.W. Chorioangioma of the placenta: Report of two cases with ultasound study. Obstet Gynecol 57:46S, 1981.

5. PHILIPPE, E. - Histopathologie Placentaire, Paris, Masson \& Cie Editeurs, 1974, p 101. 